\title{
The elephant in the room
}

May 2019 sees the first of a series of guest editorials on the health effects of climate change, focusing specifically on regional issues. ${ }^{[1]}$ Since I chatted with Matthew Chersich about the concept, southern Africa suffered a massive humanitarian disaster in March 2019 in the form of Cyclone Idai, which first hit central Mozambique, effectively wiping out the coastal city of Beira, and then inflicted major damage on Zimbabwe and Malawi, as an inland tropical depression. At the time of writing, the number of people in need in Mozambique alone was 1.85 million. ${ }^{[2]}$ The devastation wrought by this major weather event on already struggling countries will be felt for many years to come. This region has suffered cyclones before. Why, now, am I relating it to climate change? Although we cannot definitively state that cyclone Idai was caused by climate change, we do know that a hotter world means more damaging cyclones, because they draw energy from the oceans, meaning that hotter oceans will result in more powerful cyclones. Mozambique is particularly vulnerable - next to a warm Indian Ocean, with a long coastline. The science says that we can expect many more, of increasing ferocity and increasing frequency.

On 8 October 2018, the United Nations Intergovernmental Panel on Climate Change (IPCC) released a report ${ }^{[3]}$ that stated that urgent and unprecedented changes are needed to reach the target of restricting global warming to a maximum of $1.5^{\circ} \mathrm{C}$, with even a margin of just $0.5^{\circ} \mathrm{C}$ making a dramatic difference to the global environment by 2100 .

- By 2100 , the global sea level rise would be $10 \mathrm{~cm}$ lower with global warming of $1.5^{\circ} \mathrm{C}$ compared with $2^{\circ} \mathrm{C}$.

- Extreme heatwaves would be experienced by $14 \%$ of the world's population at least once every 5 years at $1.5^{\circ} \mathrm{C}$, rising to more than a third of the planet if temperatures were to rise by $2^{\circ} \mathrm{C}$.

- Arctic sea ice would remain during most summers if warming is kept to $1.5^{\circ} \mathrm{C}$, but at a rise of $2^{\circ} \mathrm{C}$, ice-free summers are 10 times more likely, leading to greater habitat losses for polar bears, whales and sea birds.

- If warming is kept to $1.5^{\circ} \mathrm{C}$, coral reefs would still decline by 70 $90 \%$, but if temperatures rise by $2^{\circ} \mathrm{C}$, virtually all of the world's coral reefs will be lost.
The world is currently $1{ }^{\circ} \mathrm{C}$ warmer than pre-industrial levels. The IPCC report makes it clear that climate change is already happening - evidenced by devastating hurricanes in the USA, record droughts in Cape Town, forest fires in the Arctic, and now Cyclone Idai. This has led to the IPCC upgrading its risk warning from previous reports, warning that every fractional additional increase in warming will make the impact worse.

We can continue to push the barriers of science to find new and more effective ways of fighting disease. We can hope that political will, global finance and the constant efforts of organisations such as the World Health Organization will improve public health. But until we take notice of the elephant in the room, climate change, all our efforts will be for naught. I won't still be alive in 2100, and I have no children. Some of you may be - and most of you at least have children and grandchildren to whom you are bequeathing the planet. Sit up and take notice. This is the single most important issue that faces us all today.

\section{Bridget Farham \\ Editor \\ ugqirha@iafrica.com}

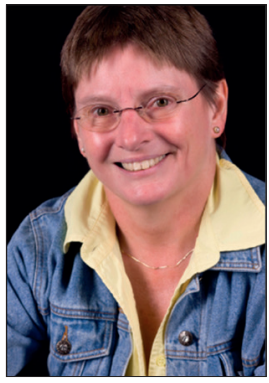

1. Chersich M. Will global warming undo the hard-won gains of prevention of mother-to-child transmission of HIV? S Afr Med J 2019:109(5):287-288, https://doi.org/10.7196/SAMJ.2019. v109i5.13988

2. United States Agency for International Development (USAID). Southern Africa - Tropical Cyclone Idai. 3 April 2019. https://reliefweb.int/sites/reliefweb.int/files/resources/04.03.19\%20-\%20USAIDDCHA\%20Southern\%20Africa\%20Tropical\%20Cyclone\%20Idai\%20Fact\%20Sheet $\% 20 \% 234$.pdf (accessed 4 April 2019)

3. United Nations Intergovernmental Panel on Climate Change. IPCC special report on global warming of $1.5^{\circ} \mathrm{C} .8$ October 2018. https://www.ipcc.ch/pdf/session48/pr_181008_P48_spm_en.pdf (accessed 8 April 2019).

S Afr Med J 2019;109(5):286. DOI:10.7196/SAMJ.2019.v109i5.14078 